\title{
Conventional colour fundus photography over multicolour imaging in identifying peripapillary intrachoroidal cavitation in myopic eyes
}

\author{
Ramesh Venkatesh 지, ${ }^{1}$ Arpitha Pereira 다, ${ }^{2}$ Aditi Gupta ${ }^{1}$
}

${ }^{1}$ Department of Retina and Vitreous, Narayana Nethralaya, Bangalore, India ${ }^{2}$ Ophthalmology, Abergele Hospital, Abergele, UK

\section{Correspondence to}

Dr Arpitha Pereira; arpitha.pereira@wales.nhs.uk

Accepted 16 October 2021
Check for updates

(C) BMJ Publishing Group Limited 2021. No commercial re-use. See rights and permissions. Published by BMJ.

To cite: Venkatesh $R$, Pereira A, Gupta A. BMJ Case Rep 2021:14:e246837. doi:10.1136/bcr-2021246837

\section{DESCRIPTION}

A 30-year-old man was referred by a general ophthalmologist for retina examination owing to his high myopia status. His presenting visual acuity in the right eye was 6/6 with a refraction of -2.75 dioptre sphere (DS), -2.75 dioptre cylinder (DC) at $170^{\circ}$ and that in the left eye was $6 / 9$ with a refraction of $-5.75 \mathrm{DS},-3.5 \mathrm{DC}$ at $170^{\circ}$. His intraocular pressure and anterior segment findings were normal. The right eye fundus was unremarkable. The left eye fundus showed a tilted optic disc with peripapillary atrophy and a wellcircumscribed yellow-orange peripapillary area at the inferior border of the myopic conus, suggestive of possible peripapillary intrachoroidal cavitation (ICC). The left eye retinal periphery was normal. Clinical examination findings were documented under pupillary dilatation using the conventional colour fundus photograph (CFP) with Topcon, TRC-50Dx imaging system with $50^{\circ}$ field of view and confocal scanning laser ophthalmoscope-based multicolour imaging on the Spectralis, Heidelberg machine with disc-centred $30^{\circ}$ field of view. The peripapillary ICC area was identified neither on the

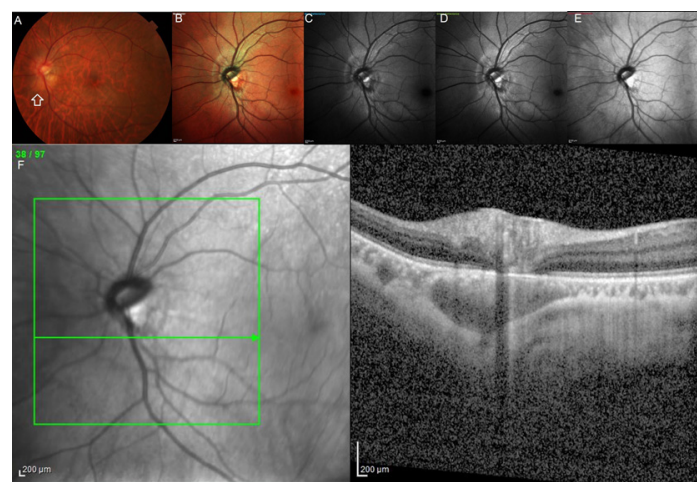

Figure 1 Imaging of peripapillary ICC using conventional colour fundus photography, multicolour imaging and spectral domain OCT: (A) on the conventional colour fundus photograph, the peripapillary ICC is seen as a well-circumscribed yellow-orange peripapillary area at the inferior border of the myopic conus (white arrow). (B-E) The multicolour image and the individual reflectance channels failed to pick up the peripapillary ICC area. (F) Spectral domain OCT through the ICC showed this area as a large intrachoroidal hyporeflective space located below the normal plane of the RPE.There was no detachment of the RPE, which appeared flat. ICC, intrachoroidal cavitation; OCT, optical coherence tomography; RPE, retinal pigment epithelium. composite multicolour image nor on any of its individual colour reflectance channels. Spectral domain optical coherence tomography (OCT) confirmed the ICC as a large intrachoroidal hyporeflective space located below the normal plane of the retinal pigment epithelium (RPE). There was no detachment of the RPE, which appeared flat (figure 1).

Peripapillary ICC in myopic eyes was first described by Freund et al on OCT as peripapillary detachment of RPE around the optic disc in pathological myopia. ${ }^{1}$ Later, Toranzo et al renamed this abnormality as 'peripapillary ICC', as this lesion was located inside the choroid and that the overlying RPE and retina were intact. ${ }^{2}$ Various theories have been described for the occurrence of peripapillary ICC in pathological myopia such as it being a congenital lesion or an acquired one occurring due to a break in the limiting membrane of Elschnig or due to excessive stretching of the weak myopic conus or due to the poor absorbing ability by the tissues of the fluid originating from the subretinal, suprachoroidal, optic canal and vitreous cavity due to ageing. ${ }^{34}$ In this clinical picture, we compare the conventional CFP and multicolour image of a patient with high myopia showing peripapillary ICC.

Multicolour imaging is a newly introduced noninvasive imaging technique wherein light of three different wavelengths (blue: $488 \mathrm{~nm}$, green: $515 \mathrm{~nm}$ and infrared: $820 \mathrm{~nm}$ ) is scanned across the retina, thus enabling an alternative method of capturing fundus images. ${ }^{5}$ The light of three different spectrums penetrate the tissue to different depths and simultaneously capture the reflectance strengths from different retinal and choroidal structures and represent the information as an en-face composite multicolour image. Specific pathological findings as in delineating epiretinal membranes and fibrovascular proliferations and for identifying reticular pseudo drusens can be visualised better with multicolour imaging. ${ }^{7-9}$ In this report, the multicolour

\section{Learning points}

This case records the presence of peripapillary intrachoroidal cavitation (ICC) in myopic eyes.

- Our case suggests that multicolour imaging does not seem to be an equivalent retinal imaging modality compared with conventional colour fundus photograph for identifying ICC in myopic eyes. 
imaging failed to identify or delineate the peripapillary ICC in comparison to the conventional CFP. The inability of the multicolour image in identifying peripapillary ICC can be explained by two reasons: (1) the inability of the blue and green reflectance channels to reach up to the choroid due to the lesser penetrance of short-wavelength light and (2) the lack of melanin within the choroidal cavitation leads to no reflectance from the higherinfrared wavelength light. ${ }^{1011}$

Contributors RV: Image analysis and paper writing; AG: data and image acquisition; AP: critical review of the manuscript.

Funding The authors have not declared a specific grant for this research from any funding agency in the public, commercial or not-for-profit sectors.

Competing interests None declared.

Patient consent for publication Consent obtained directly from patient(s).

Provenance and peer review Not commissioned; externally peer reviewed.

\section{ORCID iDs}

Ramesh Venkatesh http://orcid.org/0000-0002-4479-9390

Arpitha Pereira http://orcid.org/0000-0002-3356-1256

\section{REFERENCES}

1 Freund KB, Ciardella AP, Yannuzzi LA, et al. Peripapillary detachment in pathologic myopia. Arch Ophthalmol 2003;121:197-204.

2 Toranzo J, Cohen SY, Erginay A, et al. Peripapillary intrachoroidal cavitation in myopia. Am J Ophthalmol 2005;140:731-2.

3 Wei Y-H, Yang C-M, Chen M-S, et al. Peripapillary intrachoroidal cavitation in high myopia: reappraisal. Eye 2009;23:141-4.

4 Venkatesh R, Jain K, Aseem A, et al. Intrachoroidal cavitation in myopic eyes. Int Ophthalmol 2020;40:31-41.

5 Keane PA, Sadda SR. Retinal imaging in the twenty-first century: state of the art and future directions. Ophthalmology 2014;121:2489-500.

6 Manivannan A, Van der Hoek J, Vieira P, et al. Clinical investigation of a true color scanning laser ophthalmoscope. Arch Ophthalmol 2001;119:819-24.

7 Tan ACS, Fleckenstein M, Schmitz-Valckenberg S, et al. Clinical application of multicolor imaging technology. Ophthalmologica 2016;236:8-18.

8 Venkatesh R, Pereira A, Thomas S, et al. Subretinal drusenoid deposits versus drusen on multicolor imaging. Indian J Ophthalmol 2020;68:1450.

9 Song $\mathrm{JH}$, Moon KY, Jang S, et al. Comparison of multicolor fundus imaging and colour fundus photography in the evaluation of epiretinal membrane. Acta Ophthalmol 2019;97:e533-9.

10 Song W, Zhang L, Ness S, et al. Wavelength-dependent optical properties of melanosomes in retinal pigmented epithelium and their changes with melanin bleaching: a numerical study. Biomed Opt Express 2017;8:3966-80.

11 Lapierre-Landry M, Carroll J, Skala MC. Imaging retinal melanin: a review of current technologies. J Biol Eng 2018;12:29.

Copyright 2021 BMJ Publishing Group. All rights reserved. For permission to reuse any of this content visit

https://www.bmj.com/company/products-services/rights-and-licensing/permissions/

BMJ Case Report Fellows may re-use this article for personal use and teaching without any further permission.

Become a Fellow of BMJ Case Reports today and you can:

- Submit as many cases as you like

- Enjoy fast sympathetic peer review and rapid publication of accepted articles

- Access all the published articles

- Re-use any of the published material for personal use and teaching without further permission

Customer Service

If you have any further queries about your subscription, please contact our customer services team on +44 (0) 2071111105 or via email at support@bmj.com.

Visit casereports.bmj.com for more articles like this and to become a Fellow 